一論 文—

\section{ベンゾフェノンの芳香族アミン類による光還元反応と CIDEP一ミセル溶液において}

(1992 年 5 月 25 日 受理)
（日本化学会誌，1992，(12), p. 1423～1428)

(C) 1992 The Chemical Society of Japan

平田 剛**.宮川浩 一**・井早康 正 $^{* *}$ ・村井久雄*

各種ミセル環境下に持けるベンゾフェノンのアミン類との光還元反応を時間分解 ESR 法により研究 を行った。通常の溶媒を用いた場合, この化合物においてはイオンラジカルの直接検出は困難であった

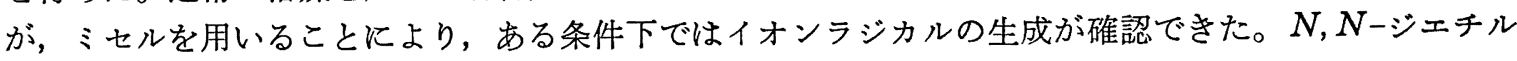
アニリンと $N, N$-ジメチルアニリンにおいては，アニオン性，カチオン性，非イオン性ミセルいずれ の場合もベンゾフェノンアニオンラジカルが検出できた。 $N$-ェチルアニリンと $N$-メチルアニリンに おいては，カチオン性ミセル（CTAB) 中でベンゾフェノンアニオンラジカルが，他のミセル中で中性 のケチルラジカルが主に生じた。アニリンを用いた場合は，いずれのミセルにおいても中性のアニリン ラジカルとケチルラジカルが主に観測できた。これらの傾向は，各アニリン類のイオン化電位あるいは 酸化電位の大きさの順序と，上い一致を示している。ミセルを用いた場合には，このように，電荷移 動, さらにイオン過程を経るある種の系に関して, 容易にイオンラジカルの分離を促進する力があると 結論付けられた。スピン分極はすべての実験に関して, 三重項機構 (TM) による全発光が主に観測さ れた。

\section{1 緒言}

ベンゾフェノン (BP) の光還元反応は，アミン類を添加するこ とにより，著しく促進されることが良く知られている。その反応 過程が電荷移動型の錯体を，あるいはさらにラジカルイオン対を 経由することを示す多くの報告がなされてさだ) 。)。著者らは時 間分解 ESR 法により, 通常の極性・無極性溶媒を用い, この光 還元反応を CIDEP (Chemically Induced Dynamic Electron Polarization) 钼測から詳細に研究し, 溶媒の極性の影響, また了 ミンの種類による反応性の違いなどを明らかにした ${ }^{778)}$ 。とくに第

大阪大学理学部, 560 豊中市待兼山町 1-1

** 電気通信大学, 182 調布市調布ヶ丘 1-5-1

1) S. G. Cohen, A. Parola, G. H. Parsons Jr., Chem. Rev., 73, 141(1973).

2) S. Arimitsu, H. Tsubomura, Bull. Chem. Soc. Jpn., 45, 2433(1972).

3) M. Hoshino, H.Shizuka, J. Phys. Chem., 91, 714 (1987).

4) L. E. Manring, K. S. Peters, J. Am. Chem. Soc., 107, 6452(1985).

5) S. Arimitsu, H. Masuhara, N. Mataga, H. Tsubomura, J. Phys. Chem., 79, 1255(1975).

6) H. Miyasaka, K. Morita, K. Kamada, N. Mataga, Bull. Chem. Soc. Jpn., 63, 3385(1990).

7) a) K. Miyagawa, H. Murai, Y. J. I'Haya, Chem. Phys. Lett., 109, 97(1984).

b) K. Miyagawa, H. Murai, Y. J. I’Haya, ibid., 118, 140(1985).

8）宮川浩一，井早康正，村井久雄，日化，1987， 1358.
一級执よび第二級アミンであるアニリン (AN)，N-メチルアニ リン (NMA)，N-ェチルアニリン（NEA）においては， N-H 結 合部位からの水素引き拔きがより速く起こることを明らかにし た。アセトニトリル中に括けるジェチルフニリン（DEA）の系に 掞いては，イオン過程を示唆する CIDEP の結果が得られた8)。 しかしながら，この手法に执いては，過渡的イオンラジカルの直 接検出には成功しなかった。

本研究においては BP とアミン類（とくに芳香族アミンを中心 に）を各種ミセル水溶液に可溶化し，時間分解 ESR 測定を行 い，通常の極性・無極性溶媒とは異なった興味深い結果が得られ たので報告する。ミセル溶液中に打ける時間分解 ESR' 法による BP の SDS 分子による光還元反応はすでに報告されておりり，得 られた異常 CIDEP 現象は，その後，スピン相関したラジカル対 として知られるにいたった ${ }^{10)}$ すすなわち，ミセル集合体中におい ては，ラジカル対としての相互作用が測定時間内で観測可能な注 ぞ強く保たれていることを示している。他方ミセル界面の性質に 関しては，多くの研究がなされて招り，イオン解離，たとえば光 イオン化による水和電子の生成，の際に電荷分離を促進するカが あることが知られている ${ }^{11}$ 。本研究では，各種アミン類と異なっ

9) Y.Sakaguchi, H. Hayashi, H. Murai, Y. J. I'Haya, Chem. Phys. Lett., 110, 275(1984).

10) a C. D. Buckley, D. A. Hunter, P. J. Hore, K. A. McLauchlan, Chem. Phys. Lett., 135, 307(1987). b) G. L. Closs, M. D. E. Forbes, J. R. Norris Jr., J. Phys. Chem., 91, 3592(1987).

11）日本化学会編，松尾 拓，“化学総説 No. 33，有機光化 学の新展開”, 学会出版センター (1982), pp. 211-228. 
た性質のミセル（アニオン性, カチオン性, 非イオン性)を組み 合わせることにより，BP アニオンラジカルが積極的に生成する 系の存在することを明らかとした。これらの系における CIDEP を測定することにより：ミセル特有の性質に関してさらに新しい 知見が得られたので, 結果を報告し，考察を行ら。

\section{2 実験}

時間分解 ESR スペクトルは, 通常の X-バンド ESR 装置 （Varian E-109）を用い，直接検波法により観測した。光源とし ては窒素ガスレーザー（Molectron UV 24, 波長 $337.1 \mathrm{~nm}$ ) を $20 \mathrm{~Hz}$ の絽り返しで用いた。信号はボックスカー積分器 (NF BX-531) で積算しながら, 磁場掃引を行い, 記録した。溶液は窒 素ガスでバブリングすることにより脱酸素を行い, ESR キャビ ティー内の平面セル（光路 $0.3 \mathrm{~mm}$ ）中を流しながら測定を行っ

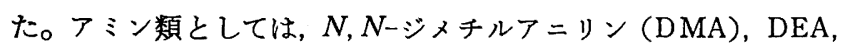
NMA，NEA，AN を用いた。BP とアミン類の精製は前報と同様 に行っだ゚。

ミセル溶液は以下のように調製を行った。アニオン性, カチオ ン性, 非イオン性の 3 種類のミセルを形成するものとして, 硫酸 ドデシルナトリウム (SDS, 関東化学 G. R. 級), セチルトリメ チルアンモニウムブロミド (CTAB, 関東化学 G. R. 級), さらに ポリ(オキシェチレン)ドデシルェーテル (Brij 35, 関東化学アミ ノ酸分光分析用) を界面活性剂としてそれぞれ用いた。これらの 界面活性剤はとくに精製せずに用いたが，一部精製して行った実 験結果と比較して，とくに差異は認められなかった。また BP 無 添加の場合は何も信号が観測されなかったため, 不純物が直接光 化学反応に関与している可能性は否定できた。すべての実験にお いて, BP の濃度は $2 \times 10^{-3} \mathrm{~mol} \mathrm{dm}^{-3}$ に, アニリン類は $1 \times$ $10^{-2} \mathrm{~mol} \mathrm{dm}^{-3}$ とし, SDS は $7 \times 10^{-2} \mathrm{~mol} \mathrm{dm}^{-3}, \mathrm{CTAB}$ は $6 \times$ $10^{-2} \mathrm{~mol} \mathrm{dm}^{-3}, \operatorname{Brij} 35$ は $4 \times 10^{-2} \mathrm{~mol} \mathrm{dm}^{-3}$ とし, 超音波洗浄器 を用いて可溶化した。この濃度関係は, 各ミセル種 $1 \mathrm{~mol} に$ 対し

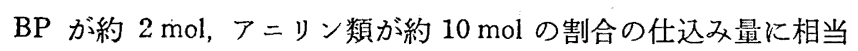
する。他の実験操作の詳細は前回の報告と同様である ${ }^{8)}$ 。

\section{3 結果と考察}

\section{1 アニオン性ミセル (SDS)}

3.1.1 DEA, DMA : 図 1-a, b に BP と DMA をSDS ミ セル中に可溶化した溶液 (以後 BP/DMA/SDS と省略して表現 する）をレーザー照射した時に得られた CIDEP スペクトルを示 した。照射㨁後は線幅が広く, ラジカル種の正確な同定は困難で あるが，1.2 $\mu \mathrm{s}$ (図 1-a), $1.8 \mu \mathrm{s}$ (図 1-b) と時間が経過するこ とにより, 全体の超微細構造（hf）が明膫となった。この全発光 型のスペクトルは BP アニオンラジカルと同定された ${ }^{12)}$ 。超微 細結合定数 $(h f c)$ を $a_{0}(4)=0.288, a_{\mathrm{m}}(4)=0.107, a_{\mathrm{p}}(2)=$ $0.353 \mathrm{mT}^{13)}$ とした場合のシミュレーションスペクトルを図 $1-\mathrm{d}$ に示した。実測スペクトルと良い一致を示している。このような 線幅変化は, CIDEP 測定の原理的な現象で,スピンの緩和時間,

12) P.H.Rieger, G.K. Fraenkel, J. Chem. Phys., 37, 2811(1962).

13） a）下付き文字は，その核種の位置を，括弧内の数字は等 価な核種の数を示している.

b ）ここで得られた光還元による $a_{0}$ と $a_{\mathrm{m}}$ の值は電極還 元の値 (Ref.12) と若干異なっていた.

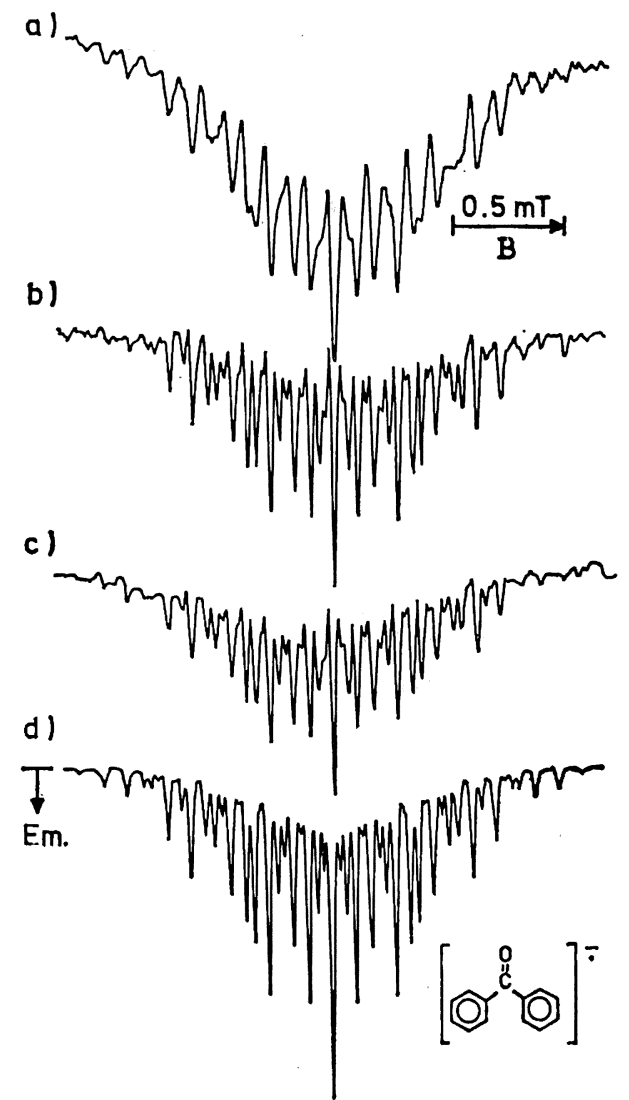

Fig. 1 Time-resolved ESR stpecra of BP/DMA/SDS (a) (delay time $1.2 \mu \mathrm{s}$ ), (b) (delay time 1.8 $\mu \mathrm{s}$ ), (c) BP/DEA/SDS (delay time $1.8 \mu \mathrm{s}$ ). (d) Computer simulated spectra of $\mathrm{BP}^{-}$(see text)

マイクロ波の出力などの影響を受ける14)。したがって，この実験 条件下ではラジカル種の時間による変化を正確に把握することは 難しい。全発光型の CIDEP は三重項機構 (TM) によるもので あり,このミセル内に扎いて反応が BP の励起三重項状態のス ピン分極の緩和より速く起こっていることを示している。 BP/ DEA/SDS ミセル溶液を用いた結果を図 1-cに示した。やはりス ペクトルは全発光型のシャープな超微細構造を示し, BP アニオ ンラジカルと同定できた。これらの系に扣いては, 対ラジカルと 考えられる DEA および DMA のカチオンラジカルは钼測され なかった。この結果からアニオン性ミセルである SDSを用いた 場合は BP の光励起後, 項間交差によりスピン分極した励起三重 項状態となり，すみやかにミセル中あるいはミセル表面でこれら アミン類と反応することが明らかとなった。さらにミセル中でこ の反応は電荷移動状態から容易にイオン対へ分離し，さらにイオ ン対は解離へ進むと考えられる。この点は通常の極性溶媒では時 間分解 ESR 法で観測することができず, ミセルを用いた系にお けるアニオン性界面の果たす役割の重要な性質と考えられる。す なわら BP アニオンはマイナス電荷の界面でカチオン対イオンか ら効率良く分離され，引き続きプロトン移動，あるいは逆電子移 動は起こり難いためであると考えられる11) SDS ミセル中に拉 けるこの反応は次式で示される。

14) K. A. McLauchlan, "Advanced EPR", ed. A. J. Hoff, Elsevier, Amsterdam (1989) pp. 345 369. 
${ }^{3} \mathrm{BP}^{*}+\mathrm{DEA}$ (or DMA)

$$
\underset{\mathrm{SDS}}{\mathrm{BP}}{ }^{-}+\mathrm{DEA} \pm \text { (or DMA }{ }^{+} \text {) }
$$

この系に限らず，BP アニオンが観察された系においては，生成 が期待できる対イオンであるアミン類のカチオンラジカルは観測 されなかった。均一溶液においてもスピン分極したアミン類のカ チアンラジカルの報告例はまれであり，このことはこのカチオン ラジカルのスピン格子緩和あるいは反応が非常に速いためである と考觉られる。また，アニオンラジカルのスペクトルの左右対称 性がよく， RPM の寄与が現れていないことは, このラジカルの $h f c$ が小さいことのほかに，ラジカルイオン対生成初期に拈ける $\mathrm{S}-\mathrm{T}_{0}$ 混合が十分に起きていないこともその一因であると推論で きる。 $\mathrm{S}-\mathrm{T}_{0}$ 混合には $10^{-8}$ 秒程度の時間を要し ${ }^{14)}$ ，このことはミ セル界面に拈ける各イオンの分離が速いことを示唆している。

3.1.2 NMA，NEA：図 2 に NMA および NEA を還元剂と して用いた場合の時間分解 ESR スペクトルを示した。信号強度 は微弱ではあるが, やはり TM による全発光型で, DMA, DEA を用いた場合とは異なったスペクトルである。NMA の場合と NEA の場合のスペクトルは酷似しており，このことから SDS 中ではこの 2 種のアニリンは BP アニオン以外でかつ同一のラジ カル種を生成していると考えられ，最も可能なラジカルとして BP ケチルが考壳られる。したがって BP ケチルラジカルの溶液 中の $h f c$ を参考にし ${ }^{15)}$ ，ヒドロキシル基プロトンの $h f c ， a_{\mathrm{OH}}$ ，を 変化させながら得られた，最も良く実測スペクトルを説明できる シミュレーションスペクトルを図 2-c に示した。このシミュ レーションにおいて $a_{0}(4)=0.327, a_{\mathrm{m}}(4)=0.125, a_{\mathrm{p}}(2)=$

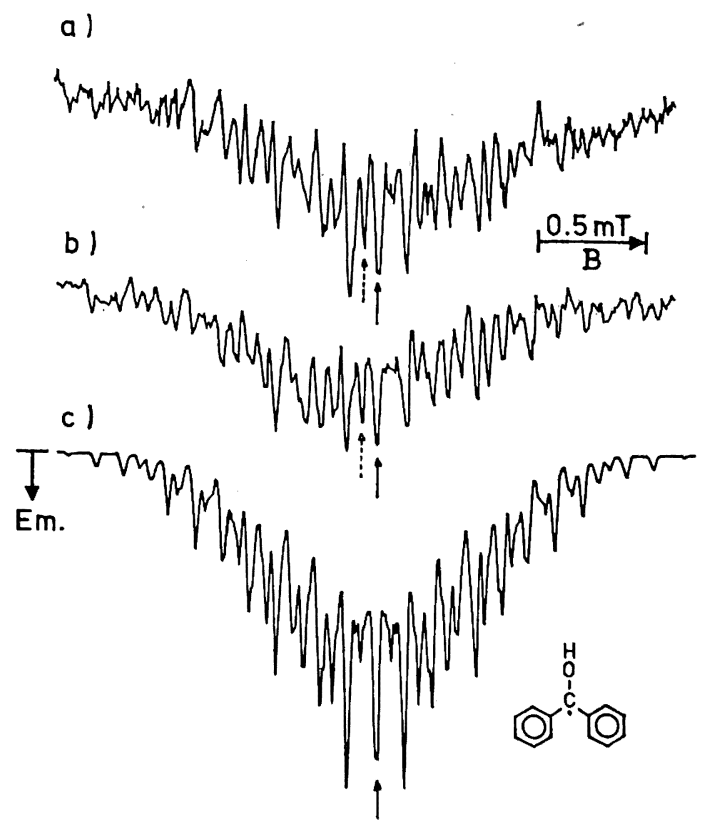

Fig. 2 Time-resolved ESR spectra (delay time $1.8 \mu \mathrm{s}$ ) of (a ) BP/NMA/SDS, (b ) BP/NEA/SDS, (c) Computer simulated spectrum of $\cdot \mathrm{BPH}$ (see tex $\mathrm{t}$ ). The solid and broken arrows indicate the center of the respective spectra of $\triangle \mathrm{BPH}$ and $\mathrm{BP}^{-}$

15) a) R. Wilson, J. Chem. Soc. B, 1970, 84.

b) R.S.Davidson, R. Wilson, J. Chem. Soc. B, 1970, 71 .
0.369， $a_{\mathrm{OH}}=0.265 \mathrm{mT}$ を用いた。したがって DMA，DEA より も大きいイオン化電位および酸化電位をもつ NMA， NEA に拉 いては(5)16)17)，結果的には水素引き抜き反応型のラシカルが主に 観測されたことになる。

$$
\begin{aligned}
& { }^{3} \mathrm{BP}^{*}+\mathrm{NMA}(\text { or NEA) } \\
& \stackrel{\mathrm{SDS}}{\mathrm{BPH}}+\cdot \mathrm{NMA} \text { (or } \cdot \mathrm{NEA})
\end{aligned}
$$

対ラジルとしての NMA や NEA からのラジカル種は観測で きなかったため，水素引き抜きが $\mathrm{N}-\mathrm{H}$ 結合から行われたかどう かはこの実験から確認できなかった。これらラジカル種はシクロ ヘキサンやアセトニトリル中では観測されているが81，信号強度 はケチルラジカルに比べると微弱であり，このため今回のミセル 系においては，はっさりとは観測されなかったと思われる。この スペクトル中には再現性良く BP アニオンラジカルの $g$ 值 $(g=$ 2.0036）の位㯰に（図中矢印）ピークが現れ，また全体としての スペクトルの複雑さも, 弱いアニオンラジカルからの信号との重 ね合わせで良く説明できる。このことは，この測定時間領域内で 中性ラジカルとともに若干のアニオンラジカルが共存しているこ とを示している。

3.1.3 AN : 図 3-a に AN を用いた結果を示した。この実験

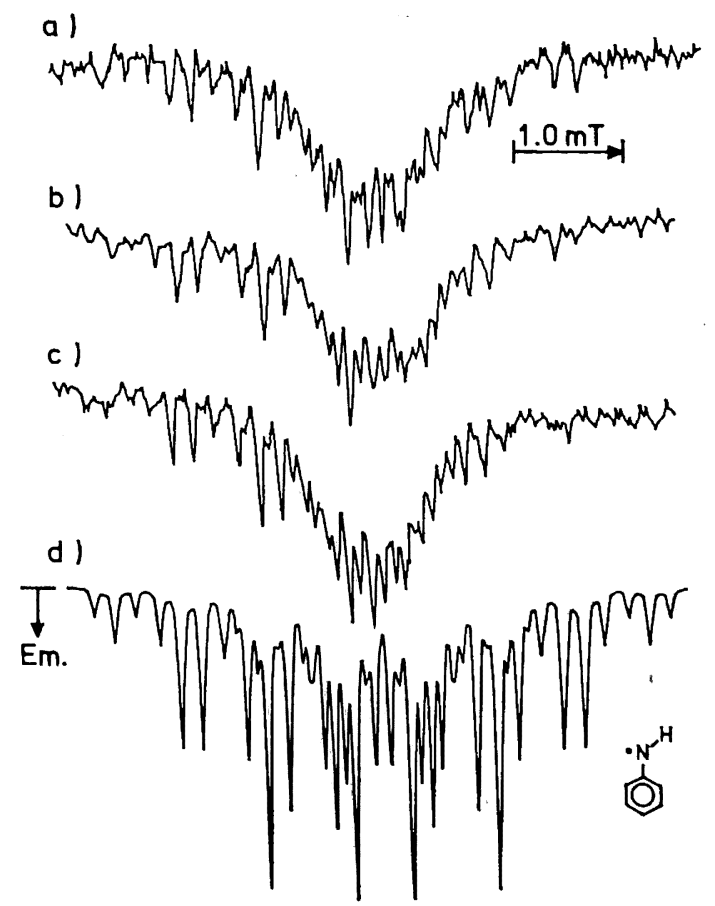

Fig. 3 Time-resolved ESR spectra (delay time 1.2 $\mu \mathrm{s}$ ) of (a) $\mathrm{BP} / \mathrm{AN} / \mathrm{SDS}$, (b) $\mathrm{BP} / \mathrm{AN} / \mathrm{CTAB}$, (c) $\mathrm{BP} / \mathrm{AN} / \mathrm{Brij} 35$, (d) Computer simulated spectrum of $\cdot A N$ (see text)

16) a) S. L. Murov, "Handbook of Photochemistry", Marcel Dekker, Inc. New York (1973) p. 197.

b) 日本化学会編, “化学便覧 (基礎槅)”, 改定版, 丸善 (1984) p. 579.

17) H. M. Rosenstock, K. Draxl, B.W.Steiner, J. T. Herron, "Journal of Physical and Chemical Reference Data", Energetics of Gaseous Ions, 6, suppl.1, American Institute of Physics, Inc., New York (1977) 
で観測された時間分解 ESR スペクトルは前に示した DMA， DEA, さらに NMA, NEAの場合と大きく異なっていたが，通常 の溶媒 (シクロヘキサン, アセトニトリル) 中 AN 存在下で観 測されたスペクトルと良い一致を示して拈り ${ }^{8)}, \mathrm{AN}$ から水素が 引き抜かれたN中心ラジカルが主に観測されているものと結論付 けられた。

$$
{ }^{3} \mathrm{BP}^{*}+\mathrm{AN} \underset{\mathrm{SDS}}{\longrightarrow} \cdot \mathrm{BPH}+\cdot \mathrm{AN}
$$

AN のイオン化電位はこの 5 種類のアミン類では一番大さい。 $h f c$ 定数を $a_{0}(2)=0.614, a_{\mathrm{m}}(2)=0.194, a_{\mathrm{p}}=0.788, a_{\mathrm{NH}}=$ $1.35, a_{\mathrm{N}}=0.780 \mathrm{mT}$ として用い, 全発光 $\mathrm{TM}$ としてシミュレー ションしたスペクトルを図 3-d に示す。スペクトルの中央部は 一致していないが, この部分は対ラジカルとしてのBP ケチルラ ジカルが重なっているためである。全体として低磁場側が強く， 高磁場側が弱いのは，三重項前駆体ジェミネートペアーRPM としての発光/吸収の重なり合いがあるためである。以上から SDS ミセルを用いた場合 DMA， DEA はイオンラジカルが， NMA，NEA，AN では中性のラジカル種が，主に生成している と結論付けられた。中性ラジカル種を生じる系では E/A 型のゆ がみがスペクトル上に認められ，直接水素引き抜き反応が起こる か，あるいは電荷分離する前に速やかにプロトン移動が起こり， 中性ラジカル対として S-T 0 混合したことを示している。

\section{2 カチオン性ミセル (CTAB)}

3.2.1 DMA, DEA：カチオン性ミセルとして CTAB を用 い, アミン類として DMA と DEA を用いて得られた時間分解 ESR スペクトルを図 4-a, b に示した。この四から明らかなよう に，DMA，DEA ともによく類似したスペクトルを示した。また このスペクトルは，DMA，DEA を SDS中で用いた場合のスペ

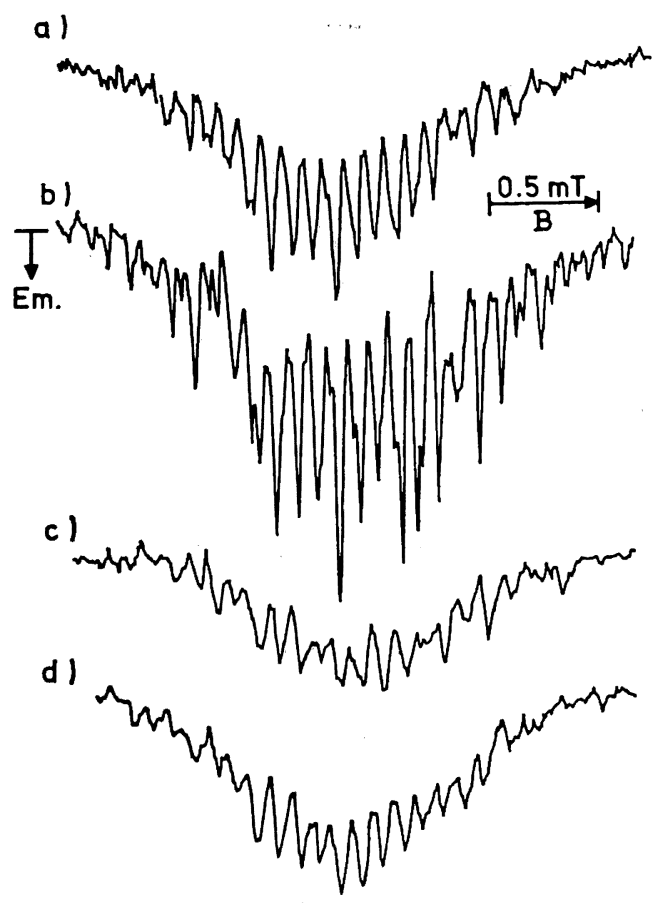

Fig. 4 Time-resolved ESR spectra of (a) BP/DMA/CTAB (delay time $1.6 \mu \mathrm{s}$ ), (b) $\mathrm{BP} / \mathrm{DEA} / \mathrm{CTAB}$ (delay time $1.8 \mu \mathrm{s}$ ), (c) $\mathrm{BP} / \mathrm{NMA} / \mathrm{CTAB}$ (delay time $1.2 \mu \mathrm{s}$ ), and (d) BP/NEA/CTAB (delay time $1.2 \mu \mathrm{s}$ )
クトルと線幅を除いて，良い一致を示している。信号はすべて全 発光で, 各超微細構造線の強度の対称性は若干くずれている。

$$
\begin{aligned}
& { }^{3} \mathrm{BP}^{*}+\mathrm{DMA} \text { (or DEA) } \\
& \left.\underset{\mathrm{CTAB}}{\mathrm{BP}} \mathrm{P}^{-}+\mathrm{DMA}^{ \pm} \text {(or DEA } \mathrm{DA}^{\circ}\right)
\end{aligned}
$$

他のラジカル種の重なり合いである可能性を完全には除くことは できないが，このスペクトルは主に BP のアニオンラジカルと同 定できた。カチオン性ミセル中に护ける BP アニオンラジカルの 線幅が，SDS ミセル中で観測されたスペクトルより広い原因と しては, CTAB のカチオン性極性基におけるアニオンラジカルの 束縛が一つの大きな要因となっているためであると考兄られる。

3.2.2 NEA, NMA：CTAB 中で得られた時間分解 ESR スペ クトルは超微細構造の分離が悪く（図 4-c, d), 解析は難しい が， BP ケチルとした場合の各超微細構造ラインのピーク位置と の対応ははなはだしく悪い。このスペクトルをBP のアニオンラ ジカルとして, DEA, DMA の CTAB 中のスペクトルと比較 すると、ピーク位置は非常に良い一致を見せた。このことから NEA, NMA は SDS ミセル中とは異なり, 主として BP アニオ ンラジカルを生成しらることが明らかとなった。

$$
\begin{aligned}
& { }^{3} \mathrm{BP}^{*}+\mathrm{NMA} \text { (or NEA) } \\
& \underset{\mathrm{CTAB}}{\mathrm{BT}} \mathrm{BP}^{-}+\mathrm{NMA} \pm \text { (or NEA }+ \text { ) }
\end{aligned}
$$

$\mathrm{CTAB}$ ミセル中に括ける NMA, NEA の存在環境には水分子が より多く浸透しており ${ }^{18)}$ ，極性が大きく，その結果，初期生成 CT 励起錯体に拈ける電荷移動の割合, さらに電荷分離の効率が 高くなり，アニオンラジカルが観測されたと考えられる。この線 幅の広いスペクトル中に他種ラジカル（とくにケチルラジカル） が重なって存在している可能性は考えられるが，この実験からは その存在は確認でさなかった。

3.2.3 AN : 図 3-b に AN を用いた場合のスペクトルを示し た。このスペクトルは AN をSDS ミセル中に可溶化した場合と 良く一致し, 全体に幅広く分布している全発光型の超微細棈造線 はやはり水素を引き抜かれたアニリンによるものと同定できた。 $\mathrm{AN}$ は $\mathrm{CTAB}$ 中でもやはり $\mathrm{N}-\mathrm{H}$ 絬合から水素原子引き抜きが 主であると結論づけられた。

$$
{ }^{3} \mathrm{BP}^{*}+\mathrm{AN} \underset{\mathrm{CTAB}}{\longrightarrow} \cdot \mathrm{BPH}+\cdot \mathrm{AN}
$$

このスペクトルの中央部は AN ラジカルのスペクトルとの重な り合いで解析が困難だが，やはりケチルラジカルが生じていると 考えられる。

\section{3 非イオン性ミセル (Brij 35)}

3.3.1 DMA, DEA : BP と DMA あるいは DEA を Brij 35 ミセル中で測定した結果を図 5-a，bにそれぞれ示した。結論 としては SDS, CTAB 中と同様に BP のアニオンラジカルが主 に生成している。やはりアニリン類のカチオンラジカルは明確に は観測できなかった。

$$
\begin{aligned}
& { }^{3} \mathrm{BP}^{*}+\mathrm{DMA} \text { (or DEA) } \\
& \left.\underset{\mathrm{Brij} 35}{\mathrm{BP}} \mathrm{BP}^{-}+\mathrm{DMA}^{+} \text {(or DEA } \mathrm{DA}^{+}\right)
\end{aligned}
$$

18) J. H. Fendler, E. J. Fendler, "Catalysis in Micellar and Macromolecular Systems", Academic Press, New York (1975). 
a)

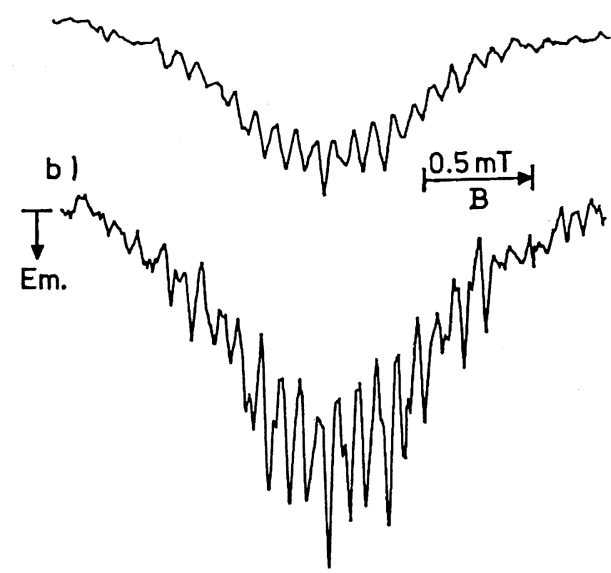

Fig. 5 Time-resolved ESR spectra of (a ) BP/ DMA/Brij 35 (delay time $1.2 \mu \mathrm{s}$ ) and (b) $\mathrm{BP} / \mathrm{DEA} / \mathrm{Brij} 35$ (delay time $1.6 \mu \mathrm{s}$ )

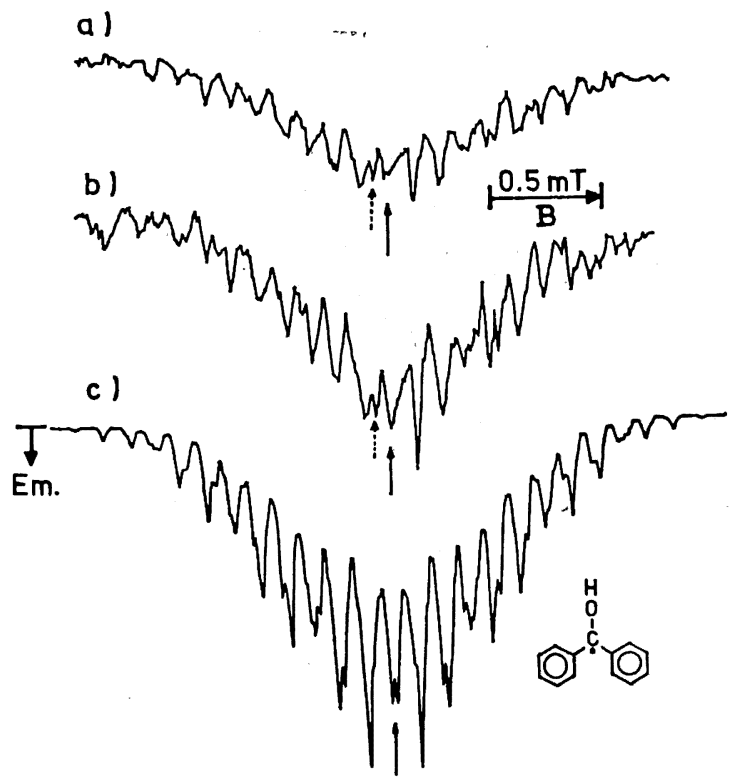

Fig. 6 Time-resolved ESR spectra (delay time $1.6 \mu \mathrm{s}$ ) of (a) BP/NMA/Brij 35, (b ) BP/NEA/Brij35, (c) Computer simulated spectrum of $\cdot \mathrm{BPH}$ (see text). The solid and broken arrows indicate the centers of respective spectra of $\cdot \mathrm{BPH}$ and $\mathrm{BP}^{-}$

DMA を用いたほうが超微細構造の分離は C'TAB 中と同様に DEA と比べてあまりよくなかった。この極性基は SDS, CTAB とは異なり, 電気的に中性で, 生じたラジカルイオンが極性基と のクーロンカで大さく反発されたり束縛されたりすることはな い。アニオンラジカルのスペクトルの線幅が SDS ミセル中にお ける結果と比較して広い原因は, 以上の理由でアニオンラジカル がバルク水相へ移動せず, 粘性の高いミ七ル内あるいは表面㬝近 くに存在しているためと考えられる。るらろん対イオンである DMA，DEA カチォンとのラジカル対としての交換相互作用 ${ }^{10)}$ ども考觉らるが, 全発光 TM であるこのスペクトルからはそ の点は議論できない。

3.3.2 NEA, NMA : 図 6-a, b に NEA, NMA を Brij 35
中に添加した結果をそれぞれ示した。やはり超微細構造の分雄は 良くなかったが，ケチルラジカルとしてのシミュレーション（ $a_{0}$ (4) $=0.327, a_{\mathrm{m}}(4)=0.125, a_{\mathrm{p}}(2)=0.369, a_{\mathrm{OH}}=0.225 \mathrm{mT}$ を使用）とピーク位置がよい一致を示したため、この場合はヶチ ルラジカルが主に生成しているものと結論付けられた。対ラジカ ルである NEA，NMA の中性ラジカルは観測にかからなかった ため，その水素引き抜き部位はこの実験に拈いては決定できなか った。シミュレーションで用いた $a_{\mathrm{OH}}$ の值が SDS 中における （図 2-c）值と大きく異なっている。この点はケチルラジカルの存 在環境が SDS と Brij35 で異なっていることを示するのであ る。このスペクトルに掉いても SDS 中と同様にアニオンラジカ ルの $g$ 中心に信号が存在し (図中矢印), 十分な解析はできない が全体のスペクトルのゆがみなどもアニオンラジカルのわずかな 混在によるものと考えられる。

3.3.3 AN : 四 3-c に示したとおり SDS, CTAB と同様, 全 発光型のアニリンラジカルが主に観測され，中央部にはケチルラ ジカルが重なっていると考えられる。AN に関してはミセルの種 類による影響は非常に小さく，常に $\mathrm{N}-\mathrm{H}$ 結合からの水素原子引 き抜き反応が主たる反応経路であると結論付けられた。

\section{4 結 び}

表 1 に以上の CIDEP の結果をまとめた。この表から明らかな ようにイオン化電位扎よび酸化電位の低いDMA，DEA に和い てはいずれのミセルに拈いても BP アニオンラジカルの生成が確 認できた。とくにアニオン性の SDS ミセルに拈いては，このア ニオンは極性基により水層に放出されたものと結論付けられた。 他のミセル中では，BP アニオンラジカルは水層に移動すること なく、ミセル内あるいはその表面に存在していると考えられる。 このことはスペクトルの線幅に現れている。NMA, NEA の場合 は, SDS ミセル中に拈いて水素引き抜き反応がより速く起きて おり，初期生成 CT 錯体における電荷移動の割合が大きくないた め, 直接水素引き抜き反応が主となったと考えられる。中性ミセ ルである Brji 35 ミセル中では，やはり水素引き抜さ反応が主に 起きている。CTAB ミセル中に拈いては，その存在環境の高い極 性のために電荷移動の割合が高くなり，BP アニオンラジカルが 観測されたと考えられる。AN においては，すべてのミセル系に おいてアニリンのN中心ラジカルが観測された。このことは AN のイオン化電位, 酸化電位が高く, 電荷移動が起こりにくいこと

Table 1 List of CIDEP results, and ionization potential (I.P.)/oxidation potential (O.P.) of aromatic amines. Parentheses indicate superposed and weak signals

\begin{tabular}{|c|c|c|c|c|c|}
\hline Amines & SDS & СТАB & Brij 35 & I.P. $\left./ \mathrm{ev}^{a}\right)$ & $O \cdot P \cdot / \mathrm{ev}^{b)}$ \\
\hline DMA & $\mathrm{BP}^{-}$ & $\begin{array}{l}\mathrm{BP}^{-} \\
\text {broad }\end{array}$ & $\begin{array}{c}\mathrm{BP}^{-} \\
\text {broad }\end{array}$ & $7.10 \sim 7.51$ & 0.71 \\
\hline DEA & $\mathrm{BP}^{-}$ & $\begin{array}{l}\mathrm{BP}^{-} \\
\text {broad }\end{array}$ & $\begin{array}{l}\mathrm{BP}^{-} \\
\text {broad }\end{array}$ & $6.99 \sim 7.51$ & 0.76 \\
\hline NMA & $\begin{array}{l}\cdot \mathrm{BPH}^{-} \\
\left(\mathrm{BP}^{-}\right)\end{array}$ & $\mathrm{BP}^{-}$ & $\stackrel{\mathrm{BPH}^{-}}{\left(\mathrm{BP}^{-}\right)}$ & $7.30 \sim 7.73$ & - \\
\hline NEA & $\begin{array}{l}\cdot \mathrm{BPH} \\
\left(\mathrm{BP}^{-}\right)\end{array}$ & $\cdot \mathrm{BP}^{-}$ & $\stackrel{\cdot \mathrm{BPH}}{\left(\mathrm{BP}^{-}\right)}$ & $7.5,7.56$ & 1.034 \\
\hline $\mathrm{AN}$ & $\begin{array}{c}\cdot \mathrm{AN} \\
(\cdot \mathrm{BPH})\end{array}$ & $\begin{array}{c}\cdot \mathrm{AN} \\
(\cdot \mathrm{BPH})\end{array}$ & $\begin{array}{c}\cdot \mathrm{AN} \\
(\cdot \mathrm{BPH})\end{array}$ & $7.61 \sim 8.08$ & 1.28 \\
\hline
\end{tabular}


に起因している。

アニオンラジカルの CIDEP スペクトルに括いて, 三重項前駆

体 RPM による El A 型の寄与は実験誤差内で積極的に確認でき

なかった。このことはアニオンラジカルの $h f c$ が小さいことの

ほかに, アニオン生成時にミセル界面で効率良く電荷分離が行わ
れ， $\mathrm{S}-\mathrm{T}_{0}$ 混合が起こるには十分な時間（１0-8 秒）がないため

と考えられる。中性ケチルラジカルに拈いても，そのスピン分極 が実験誤差以上に異常で,十分に説明できないスペクトルもあり, ミセル中におけるラジカル間の相互作用の特殊性を反映している ものと考えられる。

\title{
CIDEP Study of the Photoreduction of Benzophenone with Aromatic Amines-in Micellar Solutions
}

\author{
Tsuyoshi Hirata**, Koichi Miyagawa**, Yasumasa I'HayA** \\ and Hisao MuraI* \\ Department of Chemistry, Faculty of Science, Osaka University; \\ Toyonaka-shi 560 Japan \\ ** Department of Applied Physics and Chemistry, The University of \\ Electro-Communication; ; Chofu-shi 182 Japan
}

The reactions between photoexcited benzophenone and several aromatic amines were studied by a time-resolved ESR technique in different kind of micellar solutions (SDS, CTAB and Brij35) at room temperature. The systems of benzophenone(BP) $/ N, N$-dimethylaniline and $\mathrm{BP} / N, N$-diethylaniline showed the formation of an emissively spin-polarized benzophenone anion radical in all micellar solutions. The systems including $N$-methyl- and $N$-ethylanilines showed mainly the benzophenone ketyl radical with emissive spin-polarization in SDS and CTAB micellar solutions, and the benzophenone anion radical in Brij 35 . The systems including aniline yielded an emissively spin-polarized aniline $N$-centered radical in all the micelles. All the emissive spin-polarization observed is explained by the triplet mechanism of CIDEP. These experimental results lead to the conclusion that such micellar environments and/or interfaces promote a function of charge separation and prohibit a back charge transfer of a transient charge transfer complex or a radical-ion pair formed immediately after photolysis, when amines have low ionization potentials. 